\title{
Inhibitory effect of water extractive components from heshiko and narezushi on plasma PAI- 1 activity in rats
}

\author{
Којі Іто*
}

\begin{abstract}
The effect of water-extractive components solutions (extracts) from heshiko and narezushi, fermented mackerel products, on plasminogen activator inhibitor type-1 (PAI-1) was investigated in rats. Administration of heshiko and narezushi extracts tended to suppress the increase in both PAI-1 activity and total content associated with high-fat diet administration in rats. PAI-1 activity but not total content showed a relation to plasma triglyceride level and a reverse relation to tPA activity before and after administration of heshiko and narezushi extracts. The extracts directly inhibited PAI-1 activity in vitro, and the inhibitory activity was not lost after alimentary enzyme digestion of the extracts. The PAI-1 inhibitory activity of heshiko extract was tended to be stronger than that of narezushi extract. These results suggest that heshiko and narezushi extracts are closely involved in the promotion of fibrinolytic activity via direct PAI-1 inhibition as well as indirect suppression by decreasing the plasma triglyceride level.
\end{abstract}

Key words: fermented mackerel, fibrinolysis, latency transition, PAI-1, triglyceride

\section{Introduction}

The formation of blood clots is an important process to stop bleeding due to vascular injury. However, abnormal blood clot formation can be associated with negative events such as stroke, occurring when a blood clot occludes the blood vessel by adhesion. As a protective mechanism for circulatory system maintenance, the fibrinolytic system functions in breaking down blood clots. ${ }^{1)}$ In fibrinolysis, plasmin decomposes the fibrin fiber, the framework of the blood clot, upon activation by plasminogen activators such as urokinase and tissue-type plasminogen activator (tPA). Abnormally high fibrinolytic

Received December 24, 2015; Revision accepted April 13, 2016

* Corresponding author

Department of Marine Bioscience, Fukui Prefectural University

1-1 Gakuencho, Obama, Fukui, Japan, 917-0003

Tel: +81-770-52-9614 Fax: +81-770-52-6003

E-mail: kitou@fpu.ac.jp activity could potentially result in continuous bleeding, thus, the fibrinolytic system is regulated by the balance between promoter and inhibitor activities.

Plasminogen activator inhibitor type-1 (PAI-1) is an inhibitor of the fibrinolytic system and is a specific inhibitor of tPA. PAI-1 inhibits tPA activity by inserting a mock substrate structure, called surface-exposed reactive center loop (RCL), to active sites of tPA. ${ }^{2-4)}$ PAI-1 converts spontaneously from an active state to a latent state by burying the RCL inside the PAI-1 molecule; therefore, as has been reported, inhibitors that promote the burying of RCL, i.e., induce latency transition, are necessary to decrease PAI-1 activity and to increase tPA activity. ${ }^{2,5,6)}$

PAI-1 is a serine protease inhibitor that is mainly secreted from the endothelium, and PAI-1 expression and activity are regulated by various factors in the circulatory system. ${ }^{1)}$ For example, angiotensin II, a product of the renin-angiotensin system involved in the regulation of blood pressure, triggers the expression of PAI-1. ${ }^{7-12)}$ PAI1 expression is also increased in obesity, ${ }^{13,14)}$ and increas- 
es plasma triglyceride levels elevate PAI-1 activity. ${ }^{15-17)}$

Author already reported hypotensive and hypocholesterolemic effects as physiological functions of crude water-extractive components (extracts) from heshiko and narezushi. ${ }^{18-21)}$ Both heshiko and narezushi are Japanese traditional fermented products from salted mackerel, though there are some difference in their processing; the former is produced from salted mackerel by fermentation with rice-bran after salting raw mackerel with $20 \%$ weight of sodium chloride and the latter is done with boiled rice after salting raw mackerel with $5 \%$ weight of sodium chloride. Heshiko and narezushi commonly contain plenty of water-soluble components including peptides, and it was previously reported that the oral administration of heshiko and narezushi extracts delayed blood coagulation in rats in which the acceleration in fibrinolysis via increased tPA activity was involved. ${ }^{22)}$

The objective of this study was to examine the effect of heshiko and narezushi extracts on plasma PAI-1 activity in rats exhibiting increased tPA activity.

\section{Materials and Methods}

\section{Preparation of heshiko and narezushi extracts}

Water-extractive components solutions (extracts) of heshiko and narezushi, manufactured in the laboratory, were prepared according to a previously reported method. ${ }^{19,20)}$ About $10 \mathrm{~g}$ of mackerel dorsal muscle from heshiko or narezushi was homogenized with $100 \mathrm{~mL}$ of distilled water. After heating at $100^{\circ} \mathrm{C}$ for $5 \mathrm{~min}$, the homogenate was cooled to room temperature and then centrifuged at $10,000 \times g$ for $20 \mathrm{~min}$ at $2^{\circ} \mathrm{C}$. The first supernatant was decanted and $50 \mathrm{~mL}$ of distilled water was added to the precipitate to obtain a second supernatant in the same manner. The two supernatants were combined and filtered using filter paper (No. 2; Toyo, Tokyo, Japan); the filtrate was then diluted to $200 \mathrm{~mL}$ with distilled water to prepare each extract.

\section{Measurement of peptide content}

The peptide content in the extracts was determined according to the method of Lowry et al. ${ }^{23)}$ using bovine $\gamma$-globulin as the standard.

\section{Digestion of extracts}

Heshiko and narezushi extracts were digested using $1 \%$ weight of pepsin (from porcine gastric mucosa, Sigma, USA) of peptide content of the extracts at $\mathrm{pH} 2.0$ for $1 \mathrm{~h}$ at $37^{\circ} \mathrm{C}$. Digestion was stopped by adjusting the $\mathrm{pH}$ to about 7, and the digest was divided into four parts. One part was used as the pepsin digest fraction, and the remaining three parts were further digested by $1 \%$ weight of pancreatin, trypsin and $\alpha$-chymotrypsin (pancreatin from hog pancreas, Wako, Japan, and trypsin and $\alpha$-chymotrypsin from bovine pancreas, Sigma, USA) to peptide content of the extracts, respectively, at $\mathrm{pH} 8.0$ for $2 \mathrm{~h}$ at $37^{\circ} \mathrm{C}$. All parts were heated in boiling water for 10 minutes to inactivate the enzymes and then passed through filter paper (No. 2; Toyo). These conditions for digestion by each protease were selected by the time requested to level off the peptide concentration in the extracts by the method of Lowry et al. ${ }^{23)}$

\section{Animal experiments}

Rats were bred in the same manner as previously reported. $^{22)}$ Seven-week-old male Wistar S/T rats (SLC Japan, Hamamatsu, Japan) were divided into four groups of six individuals each, and housed for 1 week before the start of experiments under the following conditions: $23 \pm 2{ }^{\circ} \mathrm{C}, 55 \pm 5 \%$ relative humidity, $12: 12 \mathrm{~h}$ light:dark cycle, with ad libitum access to artificial diet (CE-2; CLEA Japan, Osaka, Japan) and sterilized tap water. One group was used for comparison before feeding, and other three groups were fed the artificial diets or high-fat diets for 30 days. The high-fat diet whose compositions were shown in Table 1 was prepared as previously described. ${ }^{22)}$ As the high-fat experimental diet contained $10 \%$ of triacylglycerol (corn oil) and $0.5 \%$ of free cholesterol, its fat energy ratio was $22.5 \mathrm{kcal} \%$ and was higher than that of the artificial diet (12.0 kcal\%). In experiment, the sodium chloride $(\mathrm{NaCl})$ solution was used as the control, and the extracts or the control were administered successively (for 30 days) to rats by stainless sonde, and both the dose (10 mg peptide/kg) and the volume $(10 \mathrm{~mL} / \mathrm{kg})$ for administration were set as described previously. ${ }^{19,20)}$ The amount of peptides from the extracts for dose $(10 \mathrm{mg}$ peptide/kg) was approximately corresponded to the aver- 
Table 1 Composition of high-fat experimental diet

\begin{tabular}{lc}
\hline Components & Composition (\%) \\
\hline Sucrose & 21.3 \\
Cornstarch & 40.0 \\
Gluten & 10.0 \\
Casein & 10.0 \\
Corn oil & 10.0 \\
Free cholesterol & 0.5 \\
Vitamin mixture $^{1}$ & 1.0 \\
Mineral mixture & \\
Sodium chloride & 3.3 \\
Choline chloride & 0.7 \\
Water & 0.2 \\
\hline
\end{tabular}

${ }^{1}$ AIN-93 (Oriental Yeast Co., Tokyo) was used as the vitamin mixture.

${ }^{2}$ AIN-93G (Oriental Yeast Co., Tokyo) was used as the mineral mixture.

age daily intake of heshiko and narezushi. The concentration of $\mathrm{NaCl}$ in the heshiko and narezushi extracts or control was adjusted to $1.0 \%$, which was equivalent to that of the heshiko extract. The care and treatment of animals conformed to the internal guidelines on animal experiments of Fukui Prefectural University.

Measurement of plasminogen activator inhibitor type1 (PAI-1) content and activity and tissue-type plasminogen activator (tPA) activity

Rats were sacrificed under diethyl ether anesthesia, and blood was drawn from the aorta. To prevent blood coagulation, $0.2 \mathrm{~mL}$ of $3.2 \%$ tri-sodium citrate solution was immediately added to $1.8 \mathrm{~mL}$ of blood and stirred well in a plastic tubes. The plasma was then separated by centrifugation at $735 \times g$ for $10 \mathrm{~min}$ at $5^{\circ} \mathrm{C}^{22)}$ The content of the total PAI-1 in plasma was measured using a commercial kit (Total Rat PAI-1 ELISA kit; Innovative Research Inc., Novi, MI, USA) according to the manufacturer's protocol. As the PAI-1 activity, the content of active state of PAI-1 was also measured using a commercial kit (Rat PAI-1 ELISA kit; Innovative Research Inc., Novi, MI, USA) according to the manufacturer's protocol. The activity of tPA in plasma was measured using a commercial kit (Rat tPA ELISA kit; Innovative Research Inc.) according to the manufacturer's protocol.

\section{Measurement of plasma triglyceride level}

The plasma triglyceride level was measured using a commercial kit (Triglyceride E-test Wako; Wako, Kyoto, Japan) according to the manufacturer's protocol.

\section{PAI-1 inhibitory activity of heshiko and narezushi extracts}

PAI-1 inhibitory activity of the extracts from heshiko and narezushi were examined by mixing the extracts with active PAI-1 solution. Peptide contents of the extracts from heshiko and narezushi were adjusted to $50 \mathrm{ng} / \mathrm{mL}$, and then the extracts were diluted to various peptide contents. A certain volume of the diluted extracts were mixed with an equal volume of $10 \mathrm{ng} / \mathrm{mL}$ of active PAI- 1 solution. After 5-min incubation at $37^{\circ} \mathrm{C}$, PAI- 1 activity of the mixture was measured using the commercial kit as mentioned above. To confirm the PAI-1 inhibitory activity of the extracts, the change of tPA activity was examined by the active PAI-1 mixing with or without the extracts. The extracts $(1 \mathrm{~mL})$ from heshiko or narezushi extract with $5 \mathrm{ng} / \mathrm{mL}$ of peptide content and $1 \mathrm{~mL}$ of active PAI-1 solution $(5 \mathrm{ng} / \mathrm{mL})$ were mixed and incubated for 5 -min at $37^{\circ} \mathrm{C}$. Then, the mixtures were added to $2 \mathrm{~mL}$ of tPA solution $(2.5 \mathrm{ng} / \mathrm{mL})$. After further incubation for 5 -min at $37^{\circ} \mathrm{C}$, the tPA activity of the mixture was measured using a commercial kit (Rat tPA ELISA kit; Innovative Research Inc.) according to the manufacturer's protocol. The combination in the $2.5 \mathrm{ng} / \mathrm{ml}$ of tPA activity and the $5 \mathrm{ng} / \mathrm{ml}$ of PAI- 1 activity in this assay media was decided on the basis of the preparatory experiment with the combinations of their various concentrations.

\section{Statistical analysis}

Data are expressed as the mean \pm standard deviation of six individuals. As the energy ratio of diet was quite different between the artificial diet and the high-fat one, statistical analyses were performed in each diet groups to examine the effects of feeding and administration of extracts. Significant differences between groups were assessed by one-way analysis of variance (ANOVA) followed by Tukey's multiple comparison test as described previously. ${ }^{22)}$ Values with different superscripts are significantly different $(\mathrm{p}<0.05)$. Correlation analysis was as- 
Table 2 Effect of administration of heshiko and narezushi extracts on growth and food intake of rats

\begin{tabular}{lccc}
\hline Artificial diet & Control & Heshiko extract & Narezushi extract \\
\hline Initial body weight $(\mathrm{g})$ & $188.7 \pm 4.75$ & $181.6 \pm 5.95$ & $178.3 \pm 2.44$ \\
Final body weight $(\mathrm{g})$ & $365.7 \pm 24.5$ & $355.2 \pm 15.0$ & $354.8 \pm 20.0$ \\
Body weight gain for 30 days $(\mathrm{g})$ & $177.0 \pm 22.6$ & $173.6 \pm 17.9$ & $176.5 \pm 20.2$ \\
Food intake (g/day) & $16.4 \pm 1.1$ & $15.5 \pm 0.2$ & $15.0 \pm 0.4$ \\
Food efficiency & $11.1 \pm 0.8$ & $11.4 \pm 0.2$ & $11.7 \pm 0.3$ \\
\hline High-fat diet & Control & Heshiko extract & Narezushi extract \\
\hline Initial body weight $(\mathrm{g})$ & $183.0 \pm 2.96$ & $182.4 \pm 3.80$ & $185.5 \pm 4.67$ \\
Final body weight $(\mathrm{g})$ & $364.9 \pm 13.2$ & $358.9 \pm 15.1$ & $361.5 \pm 19.5$ \\
Body weight gain for 30 days $(\mathrm{g})$ & $182.0 \pm 13.4$ & $176.5 \pm 12.8$ & $176.0 \pm 17.7$ \\
Food intake (g/day) & $15.8 \pm 0.6$ & $15.3 \pm 0.3$ & $15.2 \pm 0.6$ \\
Food efficiency & $11.2 \pm 0.4$ & $11.4 \pm 0.2$ & $11.6 \pm 0.5$ \\
\hline
\end{tabular}

Values are expressed as mean \pm standard deviation, $n=6$ in each group.

${ }^{1}$ Body weight gain / food intake

Table 3 Effect of administration of heshiko and narezushi extracts on PAI-1 activity, total PAI-1 content, tPA activity and triglyceride content in plasma

\begin{tabular}{lllll}
\hline & Before & \multicolumn{2}{l}{ After 30-day administration } & \\
\hline Artificial diet & & Control & Heshiko extract & Narezushi extract \\
\hline PAI-1 activity $(\mathrm{ng} / \mathrm{mL})$ & $0.07 \pm 0.01$ & $0.07 \pm 0.01$ & $0.05 \pm 0.02$ & $0.05 \pm 0.01$ \\
PAI-1 content $(\mathrm{ng} / \mathrm{mL})$ & $0.28 \pm 0.12$ & $0.26 \pm 0.05$ & $0.25 \pm 0.01$ & $0.24 \pm 0.15$ \\
tPA activity $(\mathrm{ng} / \mathrm{mL})$ & $0.09 \pm 0.02$ & $0.08 \pm 0.02$ & $0.15 \pm 0.03$ & $0.13 \pm 0.02$ \\
Triglyceride content $(\mathrm{mg} / 100 \mathrm{~mL})$ & $57.3 \pm 12.2$ & $59.3 \pm 16.3$ & $55.0 \pm 6.01$ & $55.6 \pm 4.51$ \\
\hline High-fat diet & & Control & Heshiko extract & Narezushi extract \\
\hline PAI-1 activity $(\mathrm{ng} / \mathrm{mL})$ & $0.07 \pm 0.01^{\mathrm{a}}$ & $0.28 \pm 0.16^{\mathrm{b}}$ & $0.20 \pm 0.05^{\mathrm{ab}}$ & $0.20 \pm 0.04^{\mathrm{b}}$ \\
PAI-1 content $(\mathrm{ng} / \mathrm{mL})$ & $0.28 \pm 0.12$ & $0.33 \pm 0.10$ & $0.26 \pm 0.08$ & $0.27 \pm 0.04$ \\
tPA activity $(\mathrm{ng} / \mathrm{mL})$ & $0.09 \pm 0.03$ & $0.05 \pm 0.02$ & $0.09 \pm 0.02$ & $0.08 \pm 0.02$ \\
Triglyceride content $(\mathrm{mg} / 100 \mathrm{~mL})$ & $56.9 \pm 10.8^{\mathrm{a}}$ & $96.8 \pm 19.2^{\mathrm{b}}$ & $77.8 \pm 13.9^{\mathrm{ab}}$ & $72.4 \pm 20.4^{\mathrm{ab}}$ \\
\hline
\end{tabular}

Values are expressed as mean \pm standard deviation, $n=6$ in each diet group.

Rows with different superscripts are significantly different $(\mathrm{p}<0.05)$.

sessed by least squares method to obtain coefficient of determination $\left(\mathrm{R}^{2}\right.$ values) and significance level was determined as $\mathrm{p}<0.05$.

\section{Results}

\section{Effect of heshiko and narezushi extract administra- tion on plasma PAI-1 activity}

Table 2 shows the parameters in growth and food intake of rats by feeding and administration of extracts. Despite of the kinds of diet, no differences in both growth and food intake were observed. It was already confirmed that $1 \%$ of $\mathrm{NaCl}$ solution used for control group had no effect on the systolic blood pressure of Wistar rats on the dose described in Materials and Methods (data not shown). Table 3 shows the PAI-1 activity, its total content and triglyceride content in plasma of rats administered heshiko and narezushi extracts by feeding the artificial or high-fat diet. After the 30-day feeding of the artificial diet, PAI-1 activity of the control group changed minimally, and tended to decrease in the heshiko and narezushi extract groups. PAI-1 activity greatly increased in the control 
(A) PAI-1 activity

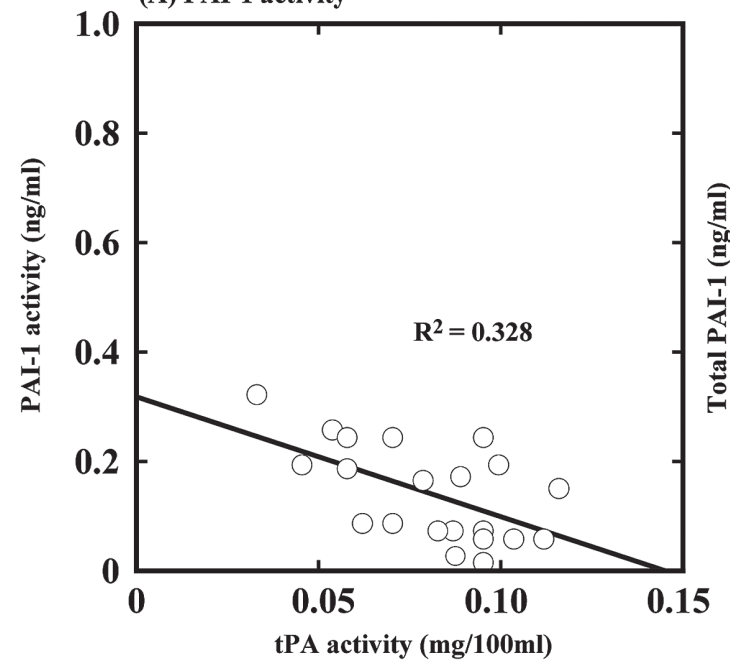

(C) PAI-1 activity

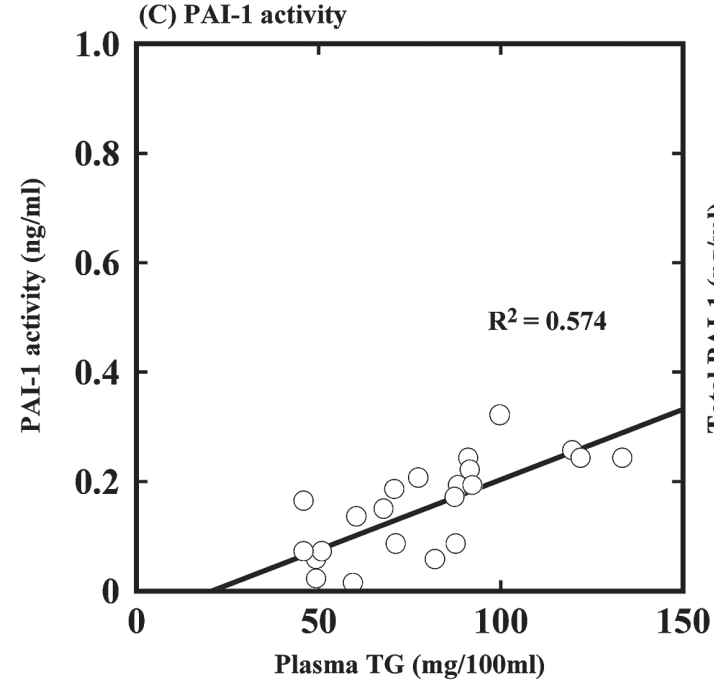

(B) Total PAI-1 content

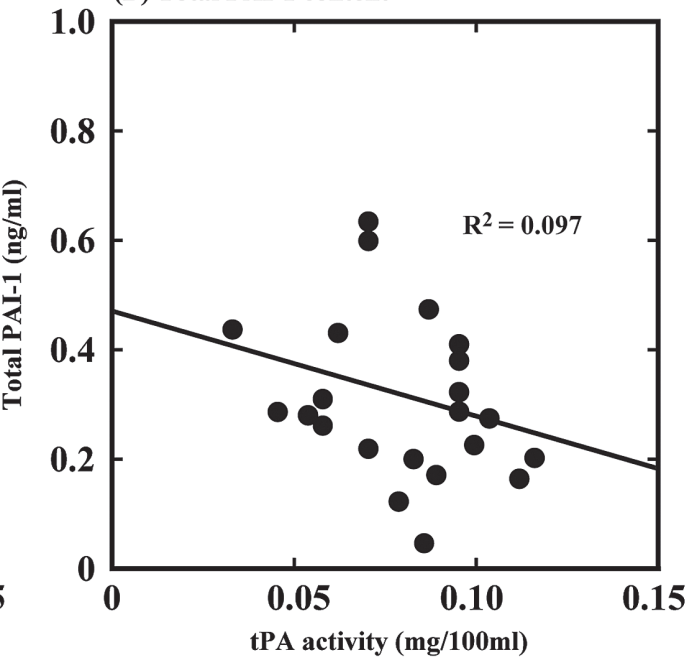

(D) Total PAI-1 content

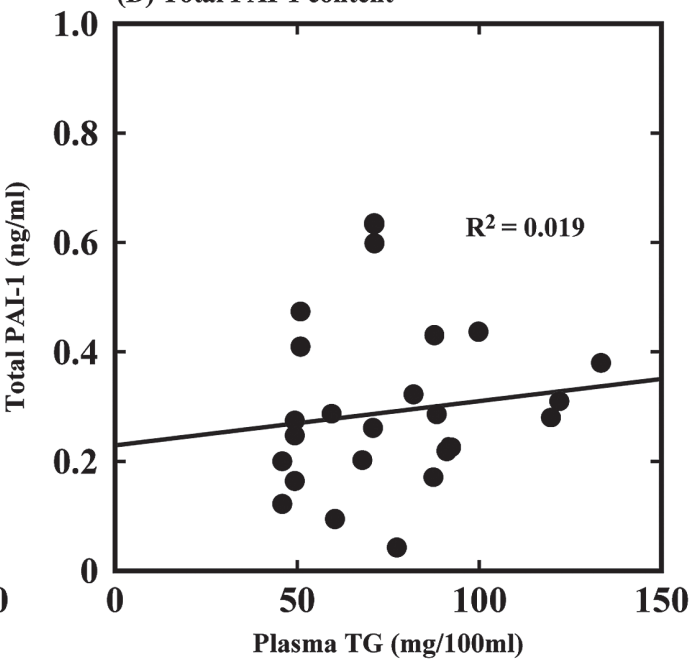

Fig. 1 Correlation between plasma PAI-1 and tPA activity or triglyceride (TG) levels (A, PAI-1 activity - tPA activity; B, total PAI-1 content - tPA activity; C, PAI-1 activity - TG level; D, total PAI-1 content - TG level) Blood samples were obtained from Wistar rats fed a high-fat diet with or without administration of heshiko and narezushi extract for 30 days.

group fed the high-fat diet; heshiko and narezushi extract administration tended to suppress this increase in PAI-1 activity.

The total PAI-1 contents in plasma of rats were also shown in Table 3. In the rats fed artificial diet, total PAI1 of the control group barely changed, and slight decreases were observed in the heshiko and narezushi extract groups. In contrast, in rats fed the high-fat diet, PAI-1 levels tended to decrease with heshiko and narezushi extract administration, with levels suppressed to almost the same as before diet feeding.

\section{Correlation between plasma PAI-1 activity or content and triglyceride level}

We calculated the $\mathrm{R}^{2}$ values to determine the correlation of tPA activity or triglyceride level in plasma to the activity or the total content of plasma PAI-1 in rats fed the high-fat diet (Fig. 1). The $\mathrm{R}^{2}$ value between PAI-1 activity and tPA activity in plasma was higher than that between total PAI-1 content and tPA activity (Fig. 1A, B). The $\mathrm{R}^{2}$ value between PAI-1 activity and plasma triglyceride level was also higher than that value between total PAI-1 content and plasma triglyceride level (Fig. 1C, D). 


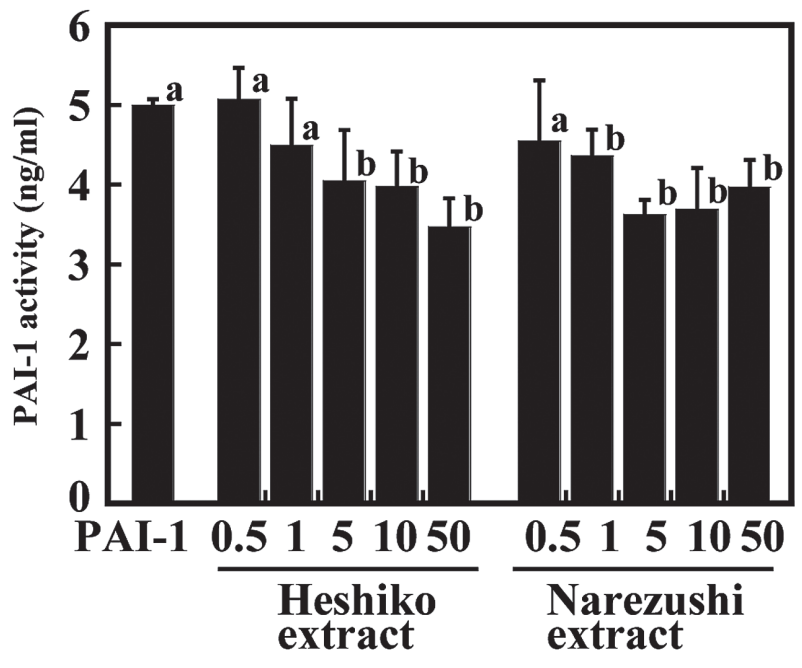

Peptide (ng/ml)

Fig. 2 PAI-1 inhibitory activity of heshiko and narezushi extracts

PAI-1 activity in the mixture was set to $5 \mathrm{ng} / \mathrm{mL}$, and the peptide content in the mixture ranged from 0.5 to $50 \mathrm{mg} / \mathrm{mL}$. Values are expressed as mean \pm standard deviation, $n=6$ in each group. Values with different superscripts are significantly different $(\mathrm{p}<0.05)$

About the $\mathrm{P}$ value for the correlation coefficient, the $\mathrm{P}$ values between plasma PAI-1 activity and tPA activity or triglyceride level were below 0.001 (Fig. 1A, C) and less than the significance level $(\mathrm{p}<0.05)$.

\section{Effect of heshiko and narezushi extracts on PAI-1} activity

The inhibitory effect of heshiko and narezushi extract on PAI-1 activity is shown in Fig. 2. The decline of activity in PAI-1 by premix with the extracts was stable within 30 minutes, the mixing PAI-1 with extracts was thought to utilize for the measurement of PAI-1 inhibitory activity. Little change in the $5 \mathrm{ng} / \mathrm{mL}$ active PAI- 1 was observed at a peptide concentration of less than $1 \mathrm{ng} / \mathrm{mL}$, whereas a peptide concentration greater than $5 \mathrm{ng} / \mathrm{mL}$ significantly suppressed PAI-1 activity. As PAI-1 inhibits tPA activity through the formation of the PAI-1-tPA complex, the changes in TPA activity by treatment with a mixture of PAI-1 and heshiko or narezushi extract are shown in Fig. 3. The combination of PAI-1 and tPA decreased tPA activity, though the combination of PAI-1 and heshiko or narezushi extracts barely decreased tPA activity.

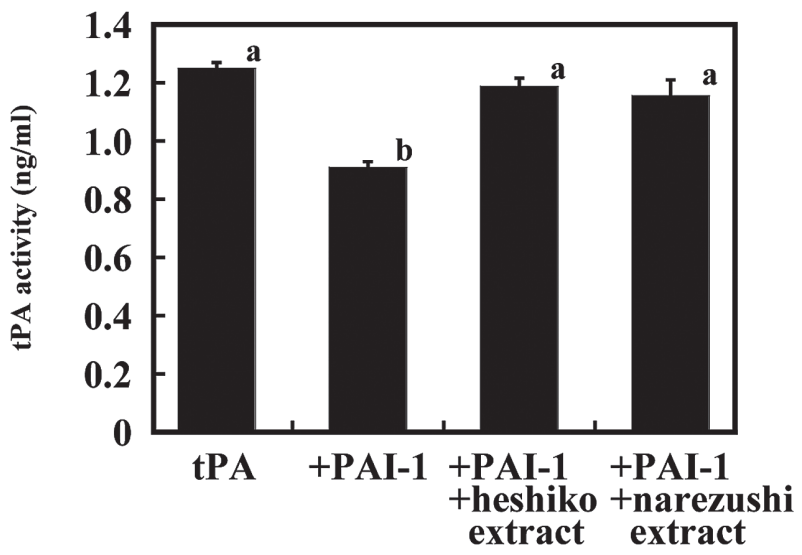

Fig. 3 Change in PA activity by treatment with premixed PAI1 solution and heshiko or narezushi extract

Active tPA solution was treated with a premixture of PAI-1 solution with and without heshiko or narezushi extract. The final activities of TPA and PAI- 1 in the samples were $1.25 \mathrm{ng} / \mathrm{mL}$ and $2.5 \mathrm{ng} / \mathrm{mL}$, respectively, and final peptide concentration of heshiko and narezushi extracts was $2.5 \mathrm{ng} / \mathrm{mL}$. Values are expressed as mean \pm standard deviation, $n=6$ in each group. Values with different superscripts are significantly different $(p<0.05)$.

\section{Effect of alimentary enzyme digestion on the PAI-1} inhibitory activity of heshiko and narezushi extracts

Figure 4 shows the changes in the PAI-1 inhibitory activity of heshiko and narezushi extracts after digestion with 4 different alimentary proteases. The inhibitory activities of the heshiko and narezushi extracts largely increased after pepsin digestion; in contrast, inhibitory activities were decreased by pancreatin, trypsin and $\alpha$-chymotrypsin treatment following pepsin digestion. However, the inhibitory activities of the digest after these treatments were maintained at least near level to undigested extracts. In any digestive treatments, activities of PAI-1 inhibited by heshiko extract tended to be lower than those by narezushi extract, but not significant.

\section{Discussion}

Inhibition by suppressors, such as antiplasmin and PAI-1, on fibrinolytic system promotes the fibrinolytic activity. ${ }^{1)}$ As the plasma tPA activity increased in the rats administered heshiko and narezushi extracts as reported previously, ${ }^{22)}$ these extracts might affect the tPA inhibi- 


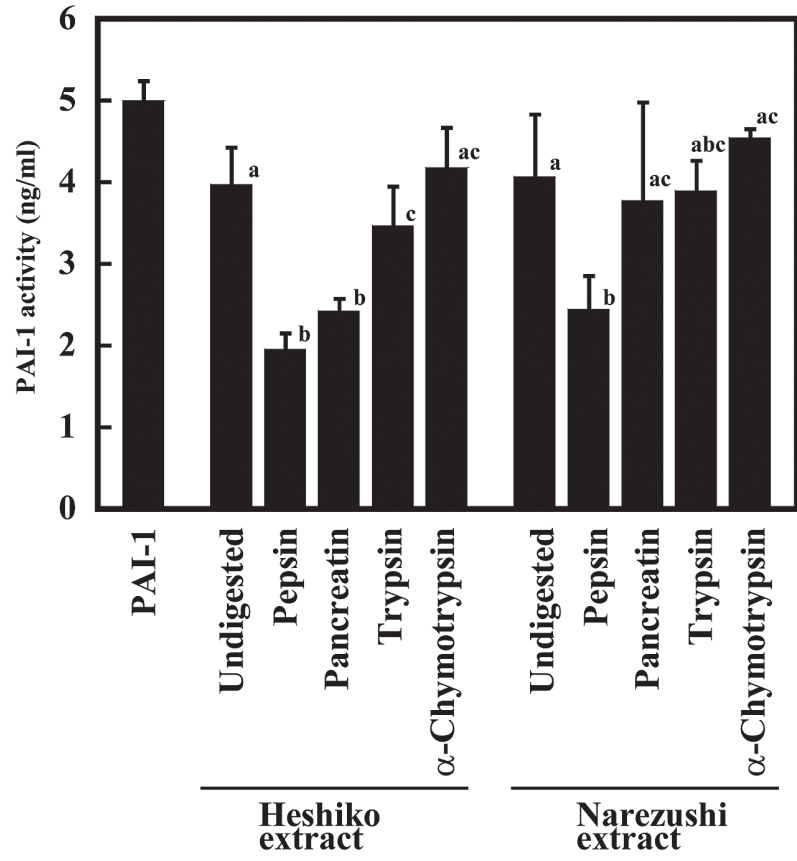

Fig. 4 Comparison of PAI-1 inhibitory activity of heshiko and narezushi extracts before and after digestion with alimentary enzymes

Values are expressed as mean \pm standard deviation, $n=6$. Values with different superscripts are significantly different in all combination of two extracts and five digestive treatments $(\mathrm{p}<0.05)$.

tor, PAI-1. As shown in Table 2, no differences were observed in the parameters in growth and food intake of rats by feeding and administration of extracts. Therefore, the changes in the PAI-1 activity, its total content and triglyceride content in plasma of rats were thought to be due to the feeding and the administrations of heshiko and narezushi extracts (Table 3).

The PAI-1 activity tended to decrease in the heshiko and narezushi extract groups, and an inverse relationship was observed between the change in PAI-1 activity during diet feeding with or without heshiko and narezushi extract administration and tPA activity (data not shown), as shown previously. ${ }^{22)}$ However, PAI-1 is mainly secreted from the endothelium of vessels, and the decrease in PAI-1 activity by heshiko and narezushi extract administration might be due to the suppression of PAI-1 secretion.

The total PAI-1 contents in plasma of rats also increased by feeding the high-fat diet, though PAI-1 levels tended to decrease with heshiko and narezushi extract administration, with levels suppressed to almost the same level as before diet feeding. From the results of Table 3, the heshiko and narezushi extracts tended to suppress the increase in both the activity and the total content of PAI1 in plasma. Then, to determine the contribution of these extracts to PAI-1 suppression, the ratio of PAI-1 activity to total content was calculated from the results shown in Table 3. The ratio increased to $85 \%$ from $25 \%$ in the high-fat diet control group; however, the ratio was suppressed to less than $77 \%$ by administration of heshiko and narezushi extracts. Moreover, by the calculations of $\mathrm{R}^{2}$ value and $\mathrm{P}$ value, the changes of the tPA activity by heshiko and narezushi extracts showed higher correlation to the PAI-1 activity than its total content (Fig. 1A, B). The suppressive tendency by extract administration was also observed in the rats fed artificial diet. These results indicate that the suppressive effect of heshiko and narezushi extracts on PAI-1 is correlated to the activity.

PAI-1 activity is regulated by various factors, and is reported to be associated with plasma triglyceride levels in humans. ${ }^{15-17,24)}$ In this study, no difference was observed in both increase of body weight and food intake of rats in each diet groups (Table 2), and the suppressive effect of heshiko and narezushi administration on the increased plasma triglyceride level in rats fed a high-fat diet was observed as previously reported (Table 3 ). ${ }^{21,22)}$ Then, the $\mathrm{R}^{2}$ value and $\mathrm{P}$ value were also calculated to determine the correlation between plasma triglyceride level and the activity or the total content of plasma PAI-1 (Fig. 1C, D). These values indicate the tendency that rats with low triglyceride levels tended to show low PAI-1 activity. This suggests that the heshiko and narezushi extracts indirectly suppressed PAI-1 activity via suppression of plasma triglyceride levels.

PAI-1 inhibits tPA via the formation of a PAI-1-tPA complex, after which PAI-1 inserts the RCL to the active site of tPA. PAI-1 loses its tPA inhibitory activity by inserting the RCL into the inside of the PAI-1 molecule as the latent state. ${ }^{2-6)}$ It is already known that small molecules including peptides can inhibit PAI-1 activity by entering into the cleft of the PAI-1 molecule as a mock substance. ${ }^{25-28)}$ As the extracts from heshiko and narezushi 
contain a large amount of peptides, ${ }^{19,20)}$ therefore, direct PAI-1 inhibition by heshiko and narezushi extracts is proposed as a possible mechanism to explain the reduced PAI-1 activity of rats shown in Table 3. Next, the PAI-1 inhibitory activity of the heshiko and narezushi extracts was examined by mixing active PAI-1 solution with the heshiko and narezushi extracts.

Heshiko and narezushi extract with a peptide concentration greater than $5 \mathrm{ng} / \mathrm{mL}$ significantly suppressed PAI-1 activity (Fig. 2), and the PAI-1 premixed with the heshiko or narezushi extracts barely decreased tPA activity (Fig. 3). Heshiko and narezushi extract were confirmed not to affect tPA activity by direct mixing (data not shown), therefore, these results indicated that the heshiko and narezushi extracts inhibit PAI-1 directly by promoting PAI-1 latency, since latent PAI-1 cannot inhibit tPA. ${ }^{2,5,6)}$ However, the extract components are ingested and absorbed in the alimentary canal prior to inhibition of plasma PAI-1. Therefore, the PAI-1 inhibitory activity of these extracts (as shown in Fig. 2) may be affected by alimentary enzymes. Since small molecules, such as TM5007 and TM5275, have been previously shown to be PAI-1 inhibitors, ${ }^{26,27)}$ we examined changes in the PAI-1 inhibitory activity of these extracts by digestion with proteases.

The PAI-1 inhibitory activities of heshiko and narezushi extracts changed after digestion with alimentary proteases, and their changes were different with the kinds of the enzymes as shown in Fig. 4. The changes in the PAI-1 inhibitory activity of these extracts by digestion were suspected to be due to the differences in amino acid sequences of $\mathrm{n}$ - or c-terminal of peptides. The PAI-1 inhibitory activity of heshiko extract tended to be stronger than that of narezushi extract with or without digestion. Both heshiko and narezushi are the fermented mackerel products, though the characters of mackerel meat such as the sodium chloride content and $\mathrm{pH}$ value were different between these products. These differences originated in their processing procedure were probably concerned in their PAI-1 inhibitory activity. Shigemura et al. reported that the peptides with small molecules from collagen hydrolysate were identified in human blood after inges- tion. ${ }^{29)}$ Therefore, these results indicate that the heshiko and narezushi extracts promote the fibrinolytic system via direct PAI-1 inhibition after digestion and absorption of peptides in the intestine.

In conclusion, it was demonstrated that the heshiko and narezushi extracts decreased PAI-1 activity in rats and that the decrease in PAI-1 activity was related to the acceleration of fibrinolysis via the increase in tPA activity. The direct PAI-1 inhibition and the suppression of plasma triglyceride levels by the heshiko and narezushi extracts were suggested to involve in the decrease in PAI1 activity.

As for the PAI-1 inhibitor(s), various low molecular weight compounds have been proved using structural analysis ${ }^{26,27)}$ however, there are few reports dealing with PAI-1 inhibitors derived from foodstuffs. Peptides have been listed as PAI-1 inhibitors, ${ }^{25)}$ and heshiko and narezushi contain large amounts of peptides as a result of the long fermentation and aging processes involved in their production. ${ }^{19}{ }^{20)}$ Therefore, it is anticipated that some peptides in these extracts are involved with the suppression of PAI-1 activity in rats. Moreover, the PAI-1 inhibitory compounds in heshiko and narezushi represent potential as heat-stable thrombolytic drugs, since these extracts were prepared using boiling water. However, the details of the peptides in the heshiko and narezushi extracts relating to the suppression of PAI-1 activity are still unclear. Therefore, an elucidation of the peptides with PAI-1 inhibitory activity from heshiko and narezushi extracts will be the subject of a future paper.

\section{Conflict of Interest}

The author declares that there is no conflict of interest.

\section{References}

1) Urano T: Fibrinolytic system. J Jpn Coll Angiol 51: 293-299, 2011 (in Japanese).

2) Dupont DM, Madsen JB, Kristensen T, Bodker JS, Blouse GE, Wind T, Andreasen PA: Biochemical properties of plasminogen activator inhibitor-1. Front Biosci 14: 1337-1361, 2009.

3) Hansen M, Busse MN, Andreasen PA: Importance of the amino-acid composition of the shutter region of plasminogen activator inhibitor-1 for its transitions to latent and substrate 
forms. Eur J Biochem 268: 6274-6283, 2001.

4) Ihara $H$ : Adipocyte-derived factors, adipokines gene regulation. Hikaku Seiri Seikagaku 26: 47-57, 2009 (in Japanese).

5) Verhamme I, Kvassman JO, Day D, Debrock S, Vleugels N, Declerck PJ, Shore JD: Accelerated conversion of human plasminogen activator inhibitor-1 to its latent form by antibody binding. J Biol Chem 274: 17511-17517, 1999.

6) Hägglöf P, Bergström F, Wilczynska M, Johansson LB, Ny T: The reactive-center loop of active PAI-1 is folded close to the protein core and can be partially inserted. J Mol Biol 335: 823-832, 2004.

7) Fukuda $D$, Sata $M$ : Role of rennin-angiotensin system in the pathogenesis of atherosclerosis. J Jpn Coll Angiol 48: 449454, 2008 (in Japanese).

8) Skurk T, Lee YM, Röhrig K, Hauner H: Effect of angiotensin peptides on PAI-1 expression and production in human adipocytes. Horm Metab Res 33: 196-200, 2001.

9) Skurk T, Lee YM, Hauner H: Angiotensin II and its metabolites stimulate PAI-1 protein release from human adipocytes in primary culture. Hypertension 37: 1336-1340, 2001.

10) Yamamoto K: PAI-1 and lifestyle-related illness. Jpn J Thromb Hemost 19: 55-63, 2008 (in Japanese).

11) Srikumar N, Brown NJ, Hopkins PN, Jeunemaitre $X$, Hunt SC, Vaughan DE, Williams GH: PAI-1 in human hypertension: relation to hypertensive groups. Am J Hypertens 15: 683-690, 2002.

12) Vaughan DE, Lazos SA, Tong K: Angiotensin II regulates the expression of plasminogen activator inhibitor-1 in cultured endothelial cells. A potential link between the renin-angiotensin system and thrombosis. J Clin Invest 95: 995-1001, 1995.

13) Landin K, Stigendal L, Eriksson E, Krotkiewski M, Risberg B, Tengborn L, Smith U: Abdominal obesity is associated with an impaired fibrinolytic activity and elevated plasminogen activator type 1. Metabolism 39: 1044-1104, 1990.

14) Shimomura I, Funahashi T, Takahashi M, Maeda K, Kotani K, Nakamura T, Yamashita S, Miura M, Fukuda Y, Takemura K, Tokunaga K, Matsuzawa Y: Enhanced expression of PAI-1 in visceral fat: possible contributor to vascular disease in obesity. Nat Med 2: 800-803, 1996.

15) Sato K, Furuya K: Hyperlipidemia and fibrinolytic system. J Jpn Obstet Gynecol Soc 45: N231-234, 1993 (in Japanese).

16) Ohni M: Hypertriglyceridaemia and thrombosis. J Clin Exp Med 164: 841-843, 1993 (in Japanese).

17) Calles-Escandon J, Mirza SA, Sobel BE, Schneider DJ: Induction of hyperinsulinemia combined with hyperglycemia and hypertriglyceridemia increases plasminogen activator inhibitor 1 in blood in normal human subjects. Diabetes 47:
290-293, 1998.

18) Itou K, Akahane Y: Antihypertensive effect of heshiko, a fermented mackerel product, on spontaneously hypertensive rats. Fish Sci 70:1121-1129, 2004.

19) Itou K, Nagahashi R, Saitou M, Akahane Y: Antihypertensive effect of narezushi, a fermented mackerel product, on spontaneously hypertensive rats. Fish Sci 73:1344-1352, 2007.

20) Itou K, Akahane Y: Effect of extracts from heshiko, a fermented mackerel product, on cholesterol metabolism in Wistar rats. Fish Sci 75:241-248, 2009.

21) Itou K, Akahane Y: Effect of extracts from narezushi, a fermented mackerel product, on cholesterol metabolism in Wistar rats. Fish Sci 76:537-546, 2010.

22) Ito K: Anticoagulating effects of water-extractive components from heshiko and narezushi, Japanese fermented aquatic products. J Nutr Sci Vitaminol 61: 84-89, 2015.

23) Lowry OH, Rosebrough NJ, Farr AL, Randall RJ: Protein measurement with the Folin phenol reagent. J Biol Chem 193: 265-275, 1951.

24) Morishita E, Asakura H, Matsuda T: Association of coagulation and fibrinolysis with hyperlipidemia. J Atheroscler Thrombs 25: 231-236, 1997.

25) Mathiasen L, Dupont DM, Christensen A, Blouse GE, Jensen JK, Gils A, Declerck PJ, Wind T, Andreasen PA: A peptide accelerating the conversion of plasminogen activator inhibitor-1 to an inactive latent state. Mol Pharmacol 74: 641-653, 2008 .

26) Izuhara $Y$, Takahashi $S$, Nangaku M, Takizawa S, Ishida $H$, Kurokawa K, van Ypersele de Strihou C, Hirayama N, Miyata $\mathrm{T}$ : Inhibition of plasminogen activator inhibitor-1: its mechanism and effectiveness on coagulation and fibrosis. Arterioscler Thromb Vasc Biol 28: 672-677, 2008.

27) Izuhara $Y$, Yamaoka $N$, Kodama $H$, Dan $T$, Takizawa $S$, Hirayama N, Meguro K, van Ypersele de Strihou C, Miyata T: A novel inhibitor of plasminogen activator inhibitor-1 provides antithrombotic benefits devoid of bleeding effect in nonhuman primates. J Cereb Blood Flow Metab 30: 904-912, 2010.

28) Hashizume $Y$, Kageyama H, Ohara K, Koibuchi Y, Inada S, Yoshida S, Kagayama A, Goto T: PAI-1 inhibitor. Vascular biology and medicine 12: 345-350, 2011.

29) Shigemura $Y$, Akaba S, Kawashima E, Park EY, Nakamura Y, Sato K: Identification of a novel food-derived collagen peptide, hydroxyprolyl-glycine, in human peripheral blood by precolumn derivatisation with phenyl isothiocyanate. Food Chem 129: 1019-1024, 2011. 